\title{
Наталія Мукан,
} доктор педагогічних наук, професор, професор кафедри педагогіки та інноваційної освіти Національний університет «Львівська політехніка» (м. Львів, Україна)

\section{Nataliya Mukan,}

Sc.D. (Education), Full Professor, Professor of the Department of Pedagogy and Innovative Education Lviv Polytechnic National University (Lviv, Ukraine) nataliya.v.mukan@lpnu.ua ORCID ID 0000-0003-4396-3408

ResearcherID: A-5027-2017

\section{Оксана Шийка,}

кандидат педагогічних наук, викладач Львівського техніко-економічного коледжу Національний університет «Львівська політехніка» (м. Львів, Україна)

\section{Oksana Shyika, \\ PhD (Education),}

Senior Instructor at Lviv Technical and Economic College, Lviv Polytechnic National University,

(Lviv, Ukraine)

shyyka@ukr.net

ORCID ID 0000-0002-0649-1205

\section{Юлія Шийка,}

кандидат педагогічних наук, доцент, доцент кафедри прикладної лінгвістики, Національний університет «Львівська політехніка» (м. Львів, Україна)

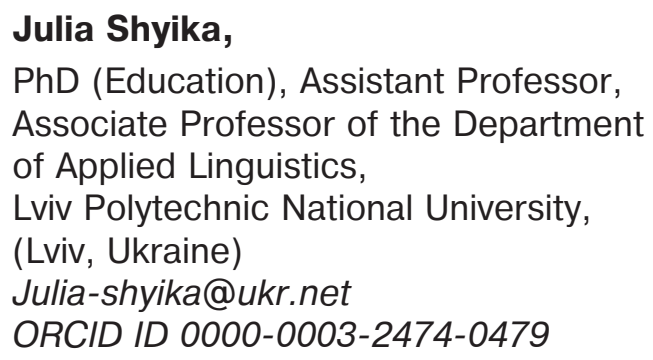

УдК 378.4.014.5 (436)

\section{СИСТЕМА ЗАБЕЗПЕЧЕННЯ ЯКОСТІ УНІВЕРСИТЕТСЬКОЇ ОСВІТИ В АВСТРІЇ}

Анотація. У Стаття присвячена аналізу специфіки сучасної системи забезпечення якості університетської освіти в Австрії на основі виконання історико-педагогічного дослідження. Відповідно до мети та завдань дослідження автори використали теоретичні та прикладні методи дослідження (описовий, статистичний, порівняльний, аналітичний метод, метод узагальнення, інтерпретації даних, логічний, структурний, системний метод, а також методи індукції і дедукції; інтерв'ю, опитування, анкетування). У статті представлена методологія аналізу забезпечення якості освіти 
в австрійських університетах. Автори висвітлюють теоретичні та методологічні основи процесу забезпечення якості університетської освіти в досліджуваній країні. Проаналізовано забезпечення якості університетської освіти в Австрії відповідно до структурно-функціональної моделі. Ця модель охоплює концептуальний, цільовий, операційний та оцінювальний компоненти. Представлено класифікацію та характеристику ресурсів дослідження якості університетської освіти в Австрії. Охарактеризовано сучасні тенденції розвитку системи забезпечення якості університетської освіти, а також виконано аналіз та порівняння європейських та австрійських стандартів кваліфікації. Автори представляють висновки з виконаного дослідження та обґрунтовують необхідність проведення подальших досліджень.

Ключові слова: Австрія; освіта; система забезпечення якості; університет.

\section{QUALITY ASSURANCE SYSTEM OF THE UNIVERSITY EDUCATION IN AUSTRIA}

Abstract. The article deals with the analysis of specificity of modern quality assurance system of the university education in Austria based on the historical and pedagogical research. According to the aim and objectives of the research, the authors used theoretical and applied research methods (descriptive, statistical, comparative, analytical, generalisation, interpretation, logical, structural, systemic methods, induction, deduction; interviews, polls, questioning). In the article, the methodology of the analysis of education quality assurance in Austrian universities has been presented. The authors highlight theoretical and methodological fundamentals of the process of quality assurance of the university education in the country under research. The authors analyse quality assurance of the university education in Austria according to the structural and functional model. This model comprises conceptual (concepts that underlie the quality assurance of university education), goal setting (goals and plan for their implementation), instrumental (mechanisms: professional, educational and cultural standards, system of conferring of educational qualification levels and scientific degrees; quality management; accreditation, assessment, ISO standards, overall quality management) and assessing components. It has been found out that the system of quality assurance of university education in Austria is being implemented in three stages: programming (analysis of the current situation, adopting of fundamental standards, clear definition of quality, its purpose, activity directions, choice of tools), implementation (choice of mechanisms, standards, ways of quality assurance, quality management; ISO standards, overall quality management, spheres of implementation (R\&D, academic process, internal services, professional development of employees), evaluation (programs, evaluation techniques, indicators of success; types of evaluation (indirect, traditional, non-traditional, content-oriented, organizational and structural). The authors present the classification and characteristics of university education quality research resources in Austria. They characterise the contemporary tendencies of the development of the system of university education quality assurance as well as analyse and compare European and Austrian qualification standards. The authors present conclusions and substantiate the necessity for further studies.

Keywords: Austria; education; quality assurance system; university.

\section{INTRODUCTION}

At the beginning of the 21st century, special attention is paid to the role of the university in the knowledge society (Mukan, Havrylyuk, \& Stolyarchuk, 2015). An increasing interest in higher education quality assurance has been developed in latest years. Recent evidence suggests that quality assurance is based on the concept of higher education as main recourse for qualified specialists training, an increase of labour productivity and competition level on the international labour market. Hence, the state investment in higher education development has been increased. This demands to raise the accountability level of universities, which offer educational services, improvement of the effectiveness of their R\&D as well as stimulation of innovative activity that is measured with the mechanisms and procedures of quality assurance system in higher education.

There is an urgent need to address the modernization of Ukrainian education according to European requirements as far as Ukraine has implemented the policy aimed at the integration into European educational and scientific space. According to the ratified Ukraine - European Union Association Agreement, the strategy of cooperation in scientific and education area, and in youth policy is being developed. It requires reformation of higher education, updating of its content and operational components, directing, and enhancing the quality of future professionals training. These outlined tasks require the introduction of quality assurance system in educational sector with the purpose to approach Ukrainian higher education to European standards, the creation of conditions for strengthening cooperation between state authorities, business, and higher educational establishments for further training of competitive human capital, which will promote high-tech and innovative development of the country. It is necessary to develop the concept of quality assurance in education, the usage of appropriate mechanisms of its realization, as well as transparent procedures of quality assessment of educational services, provided by Ukrainian universities.

Quality assurance system of higher education comprises subsystems of internal and external quality assurance, which are being developed both by universities and educational management at the national level. It is necessary to clarify, that developed European countries have relevant experience in solving the problem of higher education quality assurance. Austria is one of the leaders of European higher education space, where the level of youth unemployment is the lowest and higher education has a consistently high rating in Europe (Hernanz, \& Jimeno, 2017). Questions are mainly emphasized on high professional competence and creativity of specialist and his/her spiritual, social, multicultural development.

The analysis of scientific and pedagogical literature reveals that scientists all over the world research various aspects of higher education quality assurance in developed countries (Manatos, Sarrico, \& Rosa, 2017). A great deal of previous research into the problem of quality assurance has focused on education and educational services (Goeudevert, 2002; Keller, 2014). Different theories exist in the literature regarding higher education modernisation (Erkkilд, \& Piironen, 2014; Tight, 2014); social, political, economic aspects of higher education (Altbach, Gumport, \& Berdahl, 2011); higher education quality in the international context (Bernhard, 2012); quality of higher education 
(Bryson, 2016; Chen, Chen, \& Padry, 2017). There is a large volume of published studies describing the quality assurance of higher education (Rosa, \& Teixeira, 2014).

Pettersen study mechanisms and tools of quality assurance in university education (Pettersen, 2015). Mehta, Verma, and Seth (2013) analyse total quality management. Blanco-Ramrrez and Berger (2014), Jansen, Rosewell, and Kear (2017) research various aspects of universities' accreditation. Asif and Raouf (2013) analyse the quality of university academic process.

The results of research database analysis, as well as Ukrainian experience study, show the contradictions between dynamic development of higher education system and insufficient development of regulatory and legal, organizational, scientific and methodical support of university education quality assurance; the need for quality assurance of Ukrainian higher education and discrepancy of procedures of its realizations both on state and university level; the objective need for a comprehensive analysis of productive ideas of foreign experience of university education quality assurance and fragmentariness of its study in Ukrainian pedagogical theory and practice; the need for higher education system of Ukraine restructuring and the need for forecasting trends in its development on the basis of comprehension of the foreign experience and achievements.

So, the objective need in studying pedagogical phenomena which are typical for developed countries and searching the possibility for the application of the best results of Austrian experience has specified the topic of our research.

\section{THE AIM AND RESEARCH TASKS}

The analysis presented in this article is drawn from a broader qualitative study, examining the quality assurance system of the university education in Austria. Thus, the aim of the article is to present the research results. According to the aim we have defined the objectives, namely: to present the research methodology and historiography of the problem under research as well as to conduct analysis of the key research notions and categories; to determine the specificity of the Austrian university education development according to the tendencies of European higher education space formation; to characterise the modern system of university education quality assurance in Austria.

\section{RESEARCH METHODS}

According to the aim and objectives of our research, we used theoretical and applied research methods. There are several theoretical instruments, namely descriptive, statistical and comparative methods, available for studying the specificity of university education in Austria as well as in Ukraine. We used the analytical method for data collection, generalisation, and interpretation of theoretical and applied aspects of university education quality assurance. The logical method offered an effective way to reveal a mechanism for determining the set of notions in the sphere of quality assurance in university education. The study used structural and systemic methods to gain the insights and components of the system as well as their interrelations. We used induction and deduction to generalise the gathered theoretical and factual materials.

We have used applied methods, namely interviews with educators from University of Graz (Austria), polls and questioning of teachers etc. for gaining raw pedagogic materials.

The methodology of our research dedicated to the problem of comparative pedagogy resulted in the study of its subject based on the complex of theories, concepts, approaches which are used in pedagogy, philosophy, psychology, and economics. We emphasize on the use of systemic, complex, personal and activity-based, axiological, monographic, logical, historical, content approaches. The use of the structural and functional model of the quality assurance system of Austrian university education developed based on theses presented in the scientific works of Hцlscher and Pasternack (2008) underlie the methodology of the research.

\section{RESEARCH RESULTS}

According to the structural and functional model, the system of quality assurance in university education of Austria comprises several components: conceptual, goal setting, instrumental, and assessing.

There is some uncertainty about the terminology. The terms "education" and "educational service" are commonly used notions and yet these are concepts difficult to define precisely because of their social, philosophical, economic, pedagogical aspects. While a variety of definitions of the term "educational service" have been suggested, we determine the main characteristics of educational service. Among them, we outline imperceptibility or low degree of perceptibility; inseparability from the source of the service; changeability of the educational services quality; impossibility to conserve educational services. It should be mentioned that educational services are characterised by specific features among which there are collective consumption, the absence of a direct money equivalent, the simultaneous rendering and encouraging of spiritual values, careful attention of the society to the educational sphere, impossibility to resale etc.

Although differences of opinions still exist, there appears to be some agreement that "quality of education" refers to multidimensionality (poly-aspect) and multiple factors; dependence of the quality definition on different points of view, aspects of consideration of the educational system; interconnection with the goals of educational system functioning; the achievement of specific educational goals, which is a characteristic feature of quality. It is worth mentioning that quality level measurement involves the specialists of the educational area, consumers of educational services, and authorities, which carry out its financing, employers. So, the quality of education is a grading category.

The retrospective analysis of the Austrian university education development and functioning has shown that the number of innovative steps in the field of higher education was minimal and university traditions have not been lost. The situation has changed only after Austria became the member of the European Union.

It is important to bear in mind that Austrian universities function according to the basic principles of the Bologna Declaration. The entry of Austria into the Bologna Process has contributed to the strengthening of the requirements for the national system of education quality assurance, as well as to the search for mechanisms of internal quality assurance of educational establishments' activities. It has been found that the Law "On University" (2002) marked the new stage in the development of the Austrian system of university education. Nowadays, universities are guided by the 
principles of freedom of learning, the interconnection between scientific research and education, freedom of teaching, the active students' participation in issues related to education, internationalism, the active interaction of university staff, gender equality, social equality of chances, and consider the needs of people with special needs. The Law defines the obligation of the development and improvement of the quality assurance system of Austrian universities.

Recent research has suggested that the Agency for Quality Assurance and Accreditation Austria (AQAA) (2014), which was established in 2004, plays the main role in assuring the quality of university education. Successfully cooperating with corresponding international organizations the agency certifies the efficiency and effectiveness of the internal system of quality management in universities and promotes their further development and improvement with the help of audit.

We distinguish the ways of reforming Austrian university education, which synchronize with contemporary international trends of the development of quality assurance system in university education (drawing attention of governments and international organizations to the problems of ensuring access to education, the graduation and further employment in growing competition on the international labour market and the need to reduce spending on the training of highly skilled professionals; the spread of globalization processes, which stimulate universities and governments to ensure the quality of university education and demonstrate its ability to provide it; support of the internal European market through the free circulation of goods, services and labour), which underlie both European and Austrian qualification standards.

There is the evidence to suggest that the main reform directions of university education in Austria expect to increase the mobility of students and teachers. The current study kept track of the development of a clear and comparable system of documents and education completion according to the three-cycle system of studying (bachelor, master, and doctor degree). We found that there is the evidence of the successful implementation of the European Credit Transfer and Accumulation in the Austrian university education as well as the introduction of the modular training system. Austrians introduced the double degree programs and developed the lifelong learning system, considering the social dimensions of education. It is interesting to note the development of national qualifications framework and effective education quality assurance system. In particular, the Agency for Quality Assurance and Accreditation Austria was established and registered in the European register of agencies for higher education quality assurance (Agentur für Qualitätssicherung und Akkreditierung Austria, 2017).

As it is mentioned above, the system of quality assurance in Austrian university education comprises several components: conceptual, goal setting, instrumental, and assessing. The assessing component comprises such structural components as determining of education quality level, development of quality and assessing the quality of education. The goal-setting component covers defining the goals of education quality and drawing up an appropriate action plan. The conceptual component encompasses the concepts that underlie the implementation of education quality assurance and specific tools for education quality assurance. The instrumental component involves appropriate tools and mechanisms for quality assurance in university education of Austria.

Regarding the evaluation, target, conceptual components of the quality assurance of the Austrian university education, we have analysed the plans of the development of several Austrian universities, in particular, Karl-Franzens University of Graz, Danube University Krems, University of Innsbruck, Medicine University of Graz, Paris Lodron University of Salzburg, etc.

The use of qualitative case-study gave us the possibility to assume that the assessing component of the quality assurance system of university education in Austria is highlighted in the strategic plans of university development and involves the analysis of current situation and indicators of quality assurance (input). This comprises the introduction of the total culture of quality that is a part of the university's intellectual capital, corresponding changes in the university's strategy, optimization of all management processes, improvement of external communications, development of criteria system for assessing the quality of work of various departments and individual officials.

The current study has found that the goal setting component is a refinement of the strategic objectives of university quality management, which includes the development of effective organizational structure, development of the plan for the specific goal and objectives implementation, and the selection of appropriate tools for their achievement. The most obvious finding to emerge from the analysis is that establishing of specific goals in achieving quality indicators is based on an elaborate structure, responsibility of staff members, continuous monitoring and evaluation, interconnections at all levels. This enhances the optimization of existing tools for achieving quality, the intensive exchange of information and clarification of goals, actions and specific indicators, activation of employee participation in quality development (quality structure), improving the relationship between individual quality assurance tools as well as the implementation of planned measures in the framework of the quality audit.

Another important finding was that the conceptual component involves formulating of the concept of the university activities (development), namely, the set of key provisions defining the general direction of its functioning. The results of this study indicate that conceptual component of the quality assurance system at Austrian universities is oriented towards the general principles of quality management (Hajrizi, 2012) and international standards in the field of quality assurance in higher education. It refers to such areas of the university activities as scientific research (to ensure the quality of the educational process and increase the competitiveness of the university in the national and international educational services market). On the question of teaching and studying, this study found the massive support of students in the educational process, improvement of the content of the educational process, assessment, and improvement of the organization of teaching and studying, new ideas and concepts for improvement and further development of teaching quality. We should note the professional development of scientific and pedagogical staff of universities as an important aspect of the conceptual component. With respect to previous findings, it was found that 
Austrian universities embrace administrative (the system of strategic goals of the university, the processes of their development and the plan of achievement), financial (effective use of university funds, obtaining of external financing through the system of grants) as well as social and culture infrastructures.

The results of this study indicate that the most important mechanisms for quality assurance and management of university education in Austria are as following: audit (partner assessment, i.e. universities evaluate their own management systems and put forward recommendations for their improvement), university accreditation (assessment of universities and their curricula for compliance with certain criteria), evaluation (examination of university activities according to specific criteria and estimating the level of its competitiveness in the education service market), system of educational levels and scientific degrees provided, universities ranking (determining the position of the university according certain indexes in the education service market) (Millot, 2015), system of quality management of education (instrumental component). The audit is carried out by an independent quality assurance agency to evaluate the management system and put forward recommendations for its improvement. In Austria, private universities, the courses of which provide for a recognized educational qualification level, are accredited by the Austrian Quality Assurance and Accreditation Agency on a regular basis. One interesting finding is that Austrian universities use reflection to assess their own activities. This process involves tracking the changes in the dynamics according to separate indicators and progress in achieving the university goals.

It is interesting to note that the system of educational qualification levels and scientific degrees in Austria has its own specifics, and rating is an integral part of the educational system of the country. The analysis of the positions of Austrian universities in such world rankings of higher educational establishments as Academic Ranking of World Universities, the Times Higher Education World University Rankings, the QS World University Rankings, and others has been carried out.

According to the Austrian higher education regulatory framework, each university establishes its own quality management system and provides the mandatory verification of its functioning involving independent experts, quality control of various university activities results, conducting monitoring of compliance with educational standards with a focus on transparent international criteria of the external evaluation of university functioning.

The results of this study suggest that there is no confident interpretation of the concept "quality of education". At the same time the quality of university education is based on the close integration of philosophical, pedagogical, economic, sociological concepts and approaches that are used to characterize the significance of the category "quality" (quality as absolute assessment, quality as a property of the product, quality as a correspondence to the purpose; quality as a correspondence to the value; quality as a correspondence with standards; quality as a level of satisfaction of consumer demands). The use of these approaches provides the possibility to define its specificity in the educational field, especially its multiple-factor and multidimensional nature, dependence of its definition on the existence and functioning of interconnected components of the higher education system, the interrelation with its purpose and tasks as well as involvement of the educators, education services consumers, education authorities, employers in the definition of its level, education quality grading.

The study has confirmed the main ways of reforming university education in Austria, according to the trends typical for the process of the European Higher Education Area formation (focusing the attention of Governments and international organizations to the problem of ensuring the availability of education, its completion and further employment in the face of growing competition in the international labour market and the need to reduce spending on the training of highly skilled specialists; the spread of globalization processes, which prompt universities and governments to ensure the quality of university education and demonstrate the ability to provide it; support for the internal European market through the free circulation of goods, services and labour). Firstly, Austria created the national contact centre of the Bologna process and harmonized its national legislation with the European one in the field of higher education. Secondly, the country under research created the National agency for quality assurance and accreditation as well as established the network communication for development of cooperation in ensuring the quality of education. In addition to these activities, there is the evidence of the wide support of reforms by universities in the context of the European Higher Education Area trends.

The results of this study indicate that the strengthening of the requirements for the national system of education quality assurance and the use of mechanisms of the internal quality assurance of educational services of universities (Cardoso, Rosa, Videira, \& Amaral, 2017) has been predetermined by the accession of Austria to the Bologna Declaration. According to the structural and functional model, the system of quality assurance in Austrian university education covers conceptual (concepts that underlie the quality assurance of university education), goal setting (goals and plan for their implementation), instrumental (mechanisms: professional, educational and cultural standards, system of conferring of educational qualification levels and scientific degrees; quality management; accreditation, assessment, ISO standards, overall quality management) and assessing components. It has been found out that the system of quality assurance of university education in Austria is being implemented in three stages: programming (analysis of the current situation, adopting of fundamental standards, clear definition of quality, its purpose, activity directions, choice of tools), implementation (choice of mechanisms, standards, ways of quality assurance, quality management; ISO standards, overall quality management, spheres of implementation (R\&D, academic process, internal services, professional development of employees), evaluation (programs, evaluation techniques, indicators of success; types of evaluation (indirect, traditional, non-traditional, content-oriented, organizational and structural).

The evidence from this study suggests the broad usage of different tools to provide quality of education in modern Austrian universities. Among them, we outline traditional ones - professional communication, examination, reputation and social monitoring, didactics of higher education, the system of knowledge monitoring, autonomy, and scientific freedom, reporting etc. There are tools close to higher education sphere - assessment based on index system, 
the system of reporting and monitoring, rating, accreditation, librametrix, students polling). The Austrian universities widely use transferred from other areas instruments and algorithms of external and internal mechanisms to provide university education quality. Among them, we outline quality audit, certification focused on the success of recourse division system, benchmarking, motivation, knowledge management etc.

\section{CONCLUSION AND PROSPECTS FOR FURTHER RESEARCH}

We presented the results of the study, dedicated to examining the quality assurance system of the university education in Austria. The present study was designed to present the research methodology and historiography of the problem under research and to conduct the analysis of the key research notions and categories. We determined the specificity of the Austrian university education development according to the trends of European higher education space formation. The results of our research highlight the specificity of the system of quality assurance which comprises conceptual, goal setting, instrumental, and assessing components.

The findings of our study complement those of earlier ones and provide valuable insights into the problem under research. But there is the evidence that further studies need to be carried out to validate the detailed insights into the quality assurance system in the Austrian university education and its impact on the efficacy of university development.

\section{REFERENCES}

Agency for Quality Assurance and Accreditation Austria. (2014). Quality audit in the European higher education area: a comparison of approaches. Retrieved from: http://www.facultas.wuv.

Agentur für Qualitätssicherung und Akkreditierung Austria. (2017). Retrieved from: https://www.aq.ac.at/de/index.php

Altbach, Ph. G., Gumport, P. J., \& Berdahl, R. O. (2011). American higher education in the twenty-first century: social, political, and economic challenges. USA, Baltimore, MD: Johns Hopkins University Press. doi: 10.1353/rhe.2006.0027

Asif, M., \& Raouf, A. (2013). Setting the course for quality assurance in higher education. Quality \& Quantity, 47(4), 2009-2024. doi: 10.1007/ s11135-011-9639-2

Bernhard, A. (2012). Quality assurance in an international higher education area: a case study approach and comparative analysis. Tertiary education and management, 18(2), 153-169. doi: 10.1080/13583883.2012.654504

Blanco-Ramírez, G., \& Berger, J. B. (2014). Rankings, accreditation, and the international quest for quality: organizing an approach to value in higher education. Quality Assurance in Education, 22(1), 88-104. doi: 10.1108/QAE-07-2013-0031

Bryson, C. (2016). Engagement through partnership: students as partners in learning and teaching in higher education. International journal for academic development, 21(1), 84-86. doi: 10.1080/1360144X.2016.1124966

Cardoso, S., Rosa, M. J., Videira, P., \& Amaral, A. (2017). Internal quality assurance systems: "tailor made" or "one size fits all" implementation?" Quality assurance in education, v. 25(3), 329-342. doi: 10.1108/QAE-03-2017-0007

Chen, I-Sh., Chen, J.-K., Padró, F. F. (2017). Critical quality indicators of higher education. Total Quality Management \& Business Excellence, 28(12), 130-146. doi: 10.1080/14783363.2015.1050178

Erkkilä, T., \& Piironen, O. (2014). Shifting fundamentals of European higher education governance: competition, ranking, autonomy and accountability. Comparative education, 50(2), 177-191. doi: 10.1080/03050068.2013.807643

Goeudevert, D. (2002). Der horizont hat flügel: die zukunft der bildung. Deutschland, Berlin: Ullstein: Ullstein-Taschenbuchverl.

Hajrizi, E. (2012). Using modern management concepts and tools for developing advanced quality management systems in new higher education institutions. IFAC Proceedings Volumes, 45(10), 62-66. doi: 10.3182/20120611-3-IE-4029.00014

Hernanz, V., \& Jimeno, J. F. (2017). Youth unemployment in Europe: recent development and old problems. CESifo Forum, 2(18), 3-10.

Hölscher, M., \& Pasternack, P. (2008). Internes Qualitätsmanagement im Österreichischen Fachhochschulsektor. Zeitschrift für Hochschulrecht, Hochschulmanagement und Hochschulpolitik: ZFHR, 7(4), 97-106.

Jansen, D., Rosewell, J., \& Kear, K. (2017). Quality Frameworks for MOOCs. In: V. Jemni, J. M. Kinshuk, M. K. Khribi (Eds.). Open Education: from OERs to MOOCs. Lecture Notes in Educational Technology. Lecture Notes in Educational Technology (pp. 261-282). doi: 10.1007/978-3-662-52925-6_14

Keller, F. (2014). Strukturelle faktoren des bildungserfolgs. Wie das bildungssystem den übertritt ins berufsleben bestimmt. Deutschland, Berlin, Heidelberg: Springer.

Manatos, M. J., Sarrico, C. S., \& Rosa, M. J. (2017). The integration of quality management in higher education institutions: a systematic literature review. Total Quality Management \& Business Excellence, 28(1-2), 159-175. doi: 10.1080/14783363.2015.1050180

Mehta, N., Verma, P., \& Seth, N. (2013). Total quality management implementation in engineering education in India: an interpretive structural modelling approach. Total quality management \& Business excellence, 25(1-2), 124-140. doi: 10.1080/14783363.2013.791113

Mukan, N., Havrylyuk, M., \& Stolyarchuk, L. (2015). Theoretical Framework of Leadership in Higher Education of England and Wales. Comparative Professional Pedagogy, 5(1), 39-45. doi: 10.1515/rpp-2015-0019

Millot, B. (2015). International rankings: universities vs. higher education systems. International journal of educational development, 40, $156-165$. doi: 10.1016/j.ijedudev.2014.10.004

Pettersen, I. J. (2015). From metrics to knowledge? Quality assessment in higher education. Financial Accountability \& Management, 31(1), 23-40. doi: $10.1111 /$ faam. 12048

Rosa, M. J., \& Teixeira, P. (2014). Policy reforms, Trojan horses, and imaginary friends: the role of external stakeholders in internal quality assurance systems. Higher Education Policy, 27(2), 219-237. doi: 10.1057/hep.2013.20

Tight, M. (2014). Collegiality and managerialism: a false dichotomy? Evidence from the higher education literature. Tertiary Education and Management, 20(4), 294-306. doi: 10.1080/13583883.2014.956788 